\title{
In Silico Potential of Turmeric (Cucurma longa) as Antibacterial Agent for Salmonella typhi
}

\author{
Boni Herdiawan 1), Dwi Rulitasari ${ }^{1)}$, Ella Triana Aprilianty ${ }^{1)}$, Huzaimatul Khalisah ${ }^{1)}$, Nur \\ Fatichah Choirudiniyah ${ }^{1)}$, Jauzaa Dyah Imtiyaz ${ }^{1)}$, Erlix Rakhmad Purnama ${ }^{1)}$ \\ ${ }^{1}$ Faculty of Mathematic and Natural Science, University of Surabaya \\ email: boniherdiawan@mhs.unesa.ac.id
}

\begin{abstract}
Indonesia is a tropical country that has a variety of endemic infectious diseases, one of these diseases is typhoid fever. Salmonella typhi is a bacterium that causes typhoid fever. Antibiotic treatment is often used but fails due to bacterial resistance to antibiotics. An alternative treatment is required to gradually substitute synthetic antibiotic. One of this potential is given by turmeric (Curcuma longa).The purpose of this research was to know the potential of turmeric as in silico antibacterial agent for Salmonella typhi using docking method. Docking result showed that the five compounds produced different values on the affinity and rmsd binding parameters. The highest affinity binding value was the Ciprofloxacin compound, the lowest was Bisdemethoxycurcumin compound. The highest rmsd value was Demethoxycurcumin, while the lowest was Xanthorrhizol, and the result revealed that all compounds have bioaffinity properties. Based on the results, three compounds derived from turmeric (demethoxycurcumin, bisdemethoxy curcumin and xanthorrizol) are still not effectively used as antibacterial agent for Salmonella typhi due to the absence of equality of amino acid residues between alternative compounds turmeric with compounds which has been clinically tested as a drug and ineffective use of receptor proteins that result in less optimal alternative compounds.
\end{abstract}

\section{Keywords: Turmeric, Antibacterial, Salmonella typhi, In Silico}

\section{INTRODUCTION}

Indonesia is one of the developing countries which has various health problems, especially infectious diseases. One of this endemic infections is typhoid fever (Widodo, 2009). According to data from the World Health Organization (WHO) in 2003, there were 17 million cases of typhoid fever worldwide, with mortality reaching 600,000 cases per year. In 2000 , it was estimated that more than 2.16 million typhoid episodes occurred worldwide and there were 216,000 deaths.

Salmonella typhi is a rod-shaped gramnegative bacterium that causes typhoid fever. In general, Salmonella is pathogenic to humans when entering by mouth, however to onset an infection Salmonella must reach the small intestine.

The treatment for typhoid fever is using antibiotics such as chloramphenicol, ampicillin or amoxicillin and cotrimoxazole, however this treatment often fails due to bacterial resistance to antibiotics. For this reason, it is necessary to think of effective, efficient, safe and reasonably priced alternative medicine while still orienting towards the existing health service standards. One of those alternative treatment is to use herbal medicines. Among of all herbs, turmeric (Curcuma longa) is said to have potential in dealing with $S$. typhi.

Turmeric (Curcuma longa) is one of the plants that has long been used as traditional medicine by ancestors, this plant is in the form of shrubs and is of an annual nature distribute in tropical and sub-tropical regions. Based on the results of in vitro research conducted by Hidayati (2002), proving that the active compounds in turmeric rhizome inhibit the growth of fungi, viruses, and bacteria both Gram positive and Gram negative, such as $E$. coli and Staphylococcus aureus. This because turmeric contains various compounds including curcumin and essential oils (Said, 2001). Sesquiterpen compounds in turmeric essential oil are derivatives of terpen compounds such as alcohol which are bactericidal by damaging the tertiary structure of bacterial proteins or protein denaturation

Bioedukasi Vol. XVI. No. 2 Oktober 2018 
(Tarwiyah, 2001). While curcumin is a phenolic compound. This phenol derivative will interact with the bacterial cell wall, then absorb and penetrate into bacterial cells, causing precipitation and protein denaturation, consequently it will lyse bacterial cell membranes whereas curcumin antibacterial activity by inhibiting bacterial cell proliferation.

In addition, other compounds contained in turmeric such as bisdemethoxycurumin, demethoxycurumin, xanthorrizol, and curcumin were used as candidate compounds in th estudy. In predicting candidate compound bond interactions against protein targets, a docking process is carried out that can predict its affinity and activity. A protein called 5L3J protein (DNA gyrase sub unit B) which is a protein receptor which when bound to a compound, DNA biosynthesis will not be resolved so that bacterial cells will die (Yang et.al, 2013). The purpose of this study was to determine the potential of turmeric as an antibacterial in Salmonella typhi in silico using a docking method.

\section{RESEARCH METHOD}

All stages in this experimental study were carried out in the Laboratory of Developmental Structure and Anatomy of the Faculty of Mathematics and Natural Sciences, Surabaya State University in April 2018.

The tool used in this study consisted of a set of computers and software for the docking test which were Pyrx and Pymol. The materials used were 3D structures of Bisdemethoxycurcumin, Curcumin, Demethoxycurcumin, Xanthorrhizol, and ciprofloxacin antibiotics (as controls) which were downloaded from http://pubChem.ncbi.nml.nih.gov in the .sdf format. The 3D structure of DNA gyrase with the $5 \mathrm{~L} 3 \mathrm{~J}$ code is downloaded from the GDP of http://www.rscb.org/pdb/home.

\section{Protein Preparation}

Before preparation of the target protein, reference protein is sought, namely the DNA gyrase molecule from the Protein Data Bank (GDP) via http://www.rscb.org with the 5L3J code, then downloaded and stored in the PDB format $(*$.pdb). Subsequently preparations using Pymol software, ligands or molecules that are not used such as water molecules are removed. Then the preparation protein is stored in the format of GDP (*. Pdb).

\section{Ligan Preparation}

The ligands used in this test were Bisdemethoxycurcumin, Curcumin, Demethoxycurcumin, Xanthorrhizol, and Ciprofloxacin antibiotics as controls. The ligand data is downloaded through PubChem http://pubChem.ncbi.nml.nih.gov , selected in $3 \mathrm{D}$ and stored in SDF (*.sdf) format.

\section{Molekular Docking}

Molecular tethering/docking is done using PyRx software. The receptors that have been prepared are opened in PyRx software and the format is changed to PDBQT. Then the ligand is inserted into the open bable. Ligands are seen as minimized energy and converted to ligand format into PDBQT. After the ligand and receptor are ready, click the vina wizard and start docking. Click the receptor molecule and all the ligands to be docked. Then click forward, then position the grid box by using reference ligands as a reference to determine the active site of the receptor. After the grid box is on the ligand reference, click forward and wait until all ligands are finished. After the docking process is complete, the binding affinity is saved and the docking result ligand is analyzed for the binding site.

\section{RESULT AND DISCUSSION}

The results of docking of five compounds to the $5 \mathrm{~L} 3 \mathrm{~J}$ protein were obtained as follows (Table 1). 
Table 1. Docking Result of Compounds

\begin{tabular}{lcccc}
\hline \multicolumn{1}{c}{ Ligand } & $\begin{array}{c}\text { Binding } \\
\text { Affinity }\end{array}$ & rmsd/ub & rmsd/lb & Rmsd \\
\hline Bisdemethoxycurcumin & -6.8 & 4.943 & 3.056 & 3,9 \\
\hline Curcumin & -6.4 & 19.074 & 15.702 & 17.38 \\
\hline Demethoxycurcumin & -6.7 & 19.072 & 16.375 & 17,72 \\
\hline Xanthorrhizol & -6.6 & 3.238 & 1.44 & 2,33 \\
\hline Ciprofloxacin & -6.3 & 2.593 & 4.079 & 3,33 \\
\hline
\end{tabular}

Docking between the five compounds namely Bisdemehoxycurcumin, Curcumin, Demethoxycurcumin, Xanthorrhizol and Ciprofloxacin produced different values in affinity and rmsd binding parameters. The highest binding affinity value was Ciprofloxacin, the lowest was Bisdemethoxycurcumin. The highest rmsd value was Demethoxycurcumin, while the lowest was Xanthorrhizol.
In the Role of five test, the results revealed that all compounds have bioaffility properties. The bioavility test is a test carried out to compounds to check their ability to enter the body with several parameters, namely mass, hydrogen bond donor, hydrogen bond acceptor, and Logp. Table 2 present the data of role of five.

Table 2. Role of Five Result

\begin{tabular}{lccccc}
\multicolumn{1}{c}{ Ligand } & Mass & $\begin{array}{c}\text { H Bond } \\
\text { Donor }\end{array}$ & $\begin{array}{c}\text { H Bond } \\
\text { Acceptor }\end{array}$ & LOGP & Bioavility \\
\hline Bisdemethoxycurcumin & 308 & 2 & 4 & 3.36 & Yes \\
\hline Curcumin & 368 & 2 & 6 & 3.36 & Yes \\
\hline Demethoxycurcumin & 338 & 2 & 5 & 3.36 & Yes \\
\hline Xanthorrhizol & 218 & 1 & 1 & 4.55 & Yes \\
\hline Ciprofloxacin & 331 & 2 & 5 & -0.992 & Yes \\
\hline
\end{tabular}

In the amino acid residue test, the results obtained with several parameters, namely amino acids resulting from hydrogen bonds and hydrophobic bonds, as explained in Table 3.

Table 3. Amino Acids Residu

\begin{tabular}{llcc} 
No. & Compounds & Hydrogen Bonds & Hydrophobic Bonds \\
\hline $\mathbf{1}$ & Demethoxycurcumin & Glu219A, Gly220A, & Tyr218A, Glu227A \\
\hline $\mathbf{2}$ & Bisdemethoxycurcumin & Gln257A & Pro274A \\
\hline $\mathbf{3}$ & Xanthorrhizol & Asp37A & Asn46A, Ile78A \\
\hline $\mathbf{4}$ & Ciprofloxacin & Ser334A & - \\
$\mathbf{5}$ & Curcumin & - & - \\
\hline
\end{tabular}

The first step in drug or atibiotic design is to select the compounds that will be given to the target protein. This selection is to find out whether the compound can be absorbed by the body or cells to work on the target protein. The selection stage uses the Role of Five principle. Role of five is based on mass parameters, hydrogen bond donor, hydrogen bond acceptor, and Logp. <500, hydrogen bond donor <5, hydrogen bond acceptor $<10, \log p<5$.

Docking produces several parameters, namely Binding Affinity and RMSD. Binding affinity is the value of hydrogen bonds in a bond between a target compound and protein. The lower binding affinity signifies the energy needed to form the bond is getting smaller.

Bioedukasi Vol. XVI. No. 2 Oktober 2018 
Rmsd is the value of the distance between compounds with target proteins in amstrong units. From the docking in this study, there were some results, namely the highest binding affinity was Ciprofloxacin, the lowest was Bisdemethoxycurcumin. The highest rmsd value was Demethoxycurcumin, while the lowest was Xanthorrhizol.

In planning a drug or antibiotic design, a compound is always chosen with the lowest binding affinity in making hydrogen bonds. This is related to the effectiveness of the bond. Then the compound with the lowest rmsd is chosen because this will make the compound closer to the target protein so that the bond will be stable and the compound will work well.

In addition to Binding Affinity and Rmsd value, amino acid residues are also an important factor in testing drug ingredients. Amino acid residues are amino acids that are bound in polypeptide chains, the greater the level of similarity of amino acid residues between alternative drug ingredients and drugs that have been clinically tested, it is possible that these alternative ingredients are very effective in their treatment. From the docking results it was known that the compounds derived from turmeric (Curcuma longa), namely curcumin, demethoxycurcumin, bisdemethoxycurcumin and xanthorrizol have absolutely no amino acids with ciprofloxatin which is a comparative compound as a material that has been clinically tested in dealing with Salmonella typhi bacteria.

The mechanism of turmeric compounds (bisdemethoxycurumin, demethoxycurumin, xanthorrizol, and curcumin) as antibacterial is by inhibiting the action of DNA gyrase. DNA gyrase is a good antibacterial target for fluroquinone antibiotics because this enzyme is only present in prokaryotic cells and is important for bacterial growth (Fabrega et al., 2009). DNA gyrase plays a role in regulating DNA topology in cells. This enzyme requires energy from ATP hydrolysis to negatively catalyze supercoiling. ATP hydrolysis is a task of DNA gyrase subunit B (Mohammed et al., 2013). So that when DNA gyrase is bound by antibiotics, DNA synthesis will be disrupted and eventually cause cell death.

Mekanisme senyawa kunyit

\section{CONCLUSION}

Based on the results of the docking of curcumin compounds, demethoxycurcumin, bisdemethoxy curcumin and xanthorrizol derived from turmeric (Curcuma longa) as antibacterial agent for Salmonella typhi, it can be concluded that these compounds still cannot be effectively used to treat Salmonella typhi due to the absence of similar amino acid residues between turmeric compounds with compounds that have been clinically tested as drugs. Another reason is ineffective use of protein receptors which results in less optimal alternative compounds of turmeric in inhibiting the growth of Salmonella typhi bacteria.

\section{REFERENCES}

Fabrega, Anna dkk. 2009.Mechanism of Action and Resistance to Quinolones. Microbial Biotechnology, 2(1): 40-61.

Hidayati, E., Juli, N., Marwani, E. 2002. Isolasi Enterobacteriaceae Patogen dari Makanan Berbumbu dan Tidak Berbumbu Kunyit (Curcuma longa L.) Serta Uji Pengaruh Ekstrak Kunyit (Curcuma longa L.) Terhadap Pertumbuhan Bakteri Yang Diisolasi. Bandung: Departemen Biologi, FMIPA ITB.

Mohammed, Mona, A. 2013. Biological Evalution and Molecular Docking of Substituted Quinazolinones Antimicrobial Agents. Australia Journal of Basic and Applied Sciences, 7(2): 263274.

Said, Ahmad. 2001. Khasiat \& Manfaat Kunyit. PT. Sinar Wadja Lestari.

Tarwiyah. 2001. Minyak Atsiri Jahe. http://www.ristek.go.id. Diakses pada 6 Juni 2018.

Widodo D. Demam Tifoid. 2009. In: Sudoyo AW, editor. Buku Ajar Ilmu Penyakit Dalam Jilid III. Jakarta: Interna Publishing; 2009. p 2797-2806.

World Health Organization. 2003. Background document: The diagnosis, Treatment and

Bioedukasi Vol. XVI. No. 2 Oktober 2018 
Prevention of Typhoid Fever. Geneva: World Health Organization; 2003.

World Health Organization. 2003. Manual for the Laboratory Identification and Antimicrobial Susceptibility Testing of Bacterial Pathogens of Public Health Importance in the Developing World. Geneva: World Health Organization.

Yang, Xiang, Xue Zhang, Shui-Ping Yang and Xiao-Dong Yu. 2013. Preliminary Antibacterial Evaluation of the Chemical Composition in Herba pogostemonis Oil. Universa Medicina, 26 (1): 46-56. 